\title{
New Fluorometric Method for the Determination of Ketotifen Fumarate Using Continuous Flow Injection Analysis via ISNAG-fluorimeter
}

\author{
Nagam S. Turkie ${ }^{1}$
}

Hayder Q. Munshid ${ }^{*}$

\author{
Received 25/9/2018, Accepted 21/1/2019, Published 2/6/2019
}

This work is licensed under a Creative Commons Attribution 4.0 International License.

\begin{abstract}
:
A newly developed analytical method was conducted for the determination of Ketotifen fumarate (KTF) in pharmaceuticals drugs via quenching of continuous fluorescence of $9(10 \mathrm{H})$-Acridone (ACD). The method was applied using flow injection system of a new homemade ISNAG fluorimeter with fluorescence measurements at $\pm 90^{\circ}$ via $2 \times 4$ solar cell. The calibration graph was linear in the range of $1-45 \mathrm{mmol} / \mathrm{L}$, with correlation coefficient $\mathrm{r}=0.9762$ and the limit of detection $29.785 \mu \mathrm{g} /$ sample from the stepwise dilution for the minimum concentration in the linear dynamic ranged of the calibration graph. The method was successfully applied to the determination of Ketotifen fumarate in two different pharmaceutical drugs. A comparison was made between the newly developed method analysis and the classical method using the standard addition method via the use of individual and paired t-test and F-test. It was noticed that there was no significant difference between the two methods at $95 \%$ confidence level.
\end{abstract}

Key words: 9(10H)-Acridone, Flow injection analysis, Fluorescence, Ketotifen fumarate .

\section{Introduction:}

Ketotifen Fumarate (KTF) is an antihistaminic drug which has the nomenclature 4(1-Methylpiperidin-4-ylidene)-4,9-dihydro-10Hbenzo[4,5] cyclohepta[1,2-b] thiophen- 10-one hydrogen (E)-butenedioate (Fig. 1) with an empirical formula of $\mathrm{C}_{19} \mathrm{H}_{19} \mathrm{NOS}, \mathrm{C}_{4} \mathrm{H}_{4} \mathrm{O}_{4}$, and it is a white or brownish-yellow, fine, crystalline powder. It is sparingly soluble in water, slightly soluble in methanol, very slightly soluble in acetonitrile (1). The main biochemical and pharmacological activities of ketotifen fumarate are $\mathrm{H}_{1}$ receptor antagonism, phosphodiesterase inhibition and inhibition of calcium flux in smooth muscle preparations. All these actions are suited to prevent the development of asthmatic conditions (2). Many analytical methods have been reported for the determination of KTF in pure form and pharmaceutical preparations, which includes spectrophotometric methods (3-5), chemiluminescence $(6,7)$, electrochemical $(8-10)$, electrochemilu-minescence $(11, \quad 12)$, chromatographic $(13,14)$, and flow injection analysis (FIA) methods $(15,16,17)$.

\footnotetext{
${ }^{\mathrm{T}}$ Department of Chemistry, College of Science, University of Baghdad, Baghdad, Iraq

${ }^{2}$ Department of Pharmacy, Al-Esraa University Collage, Baghdad, Iraq

*Corresponding: Haider.qais1989@gmail.com
}

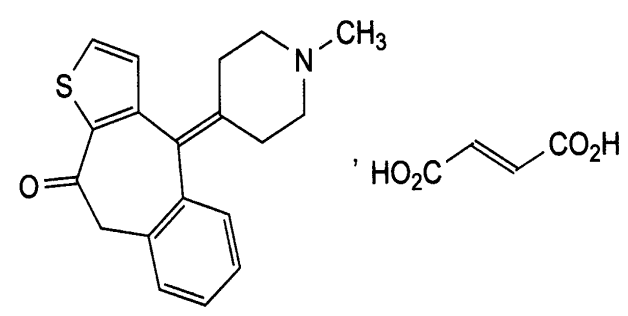

Figure1. Chemical structures of Ketotifen Fumarate.

The aim of this study was to develop a new fluorometric flow injection method for the determination of ketotifen fumarate (KTF) using the new homemade ISNAG-fluorimeter. This method is based on the quenching of $9(10 \mathrm{H})$-acridone fluorescence measured at $\pm 90^{\circ}$ via the use of ISNAG-fluorimeter. $9(10 \mathrm{H})$-Acridone (ACD) is one of the acridone alkaloids which have a characteristic of fluorescence absorption due to their specific skeleton structure (18). 9(10H)-Acridone (ACD) gives a continuous fluorescence which quenches via ketotifen fumarate (KTF) with the proposed mechanism illustrated in (scheme 1). This mechanism is based on the possibility that it might be attributed to the formation of non-fluorescent derivative or decomposition of fluorescent molecule or finally might be due to excessive collision causing quenching of fluorescence (i.e.; external conversion). 

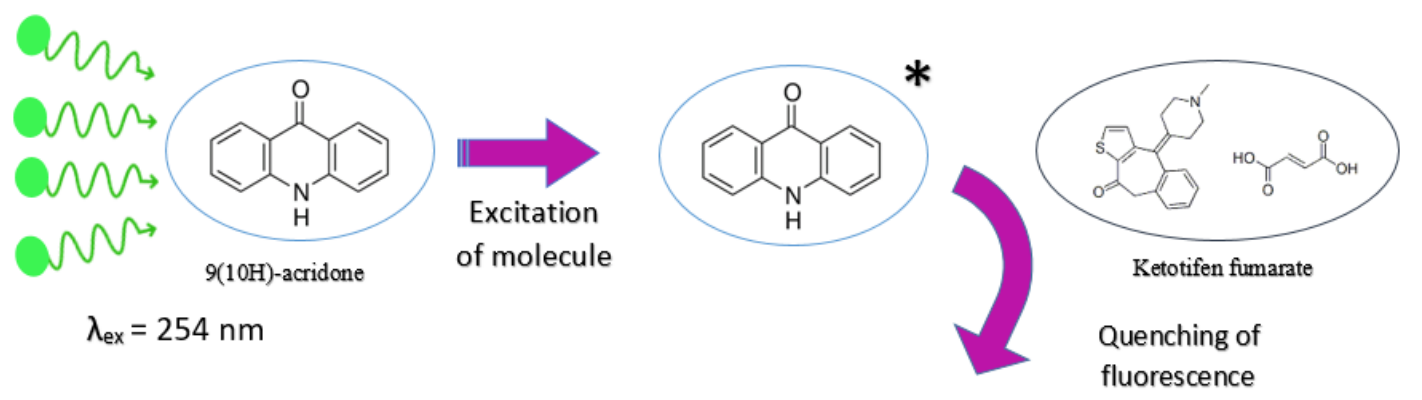

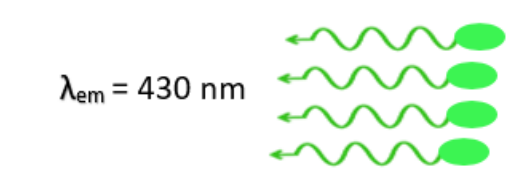

ex: excitation, em: emission
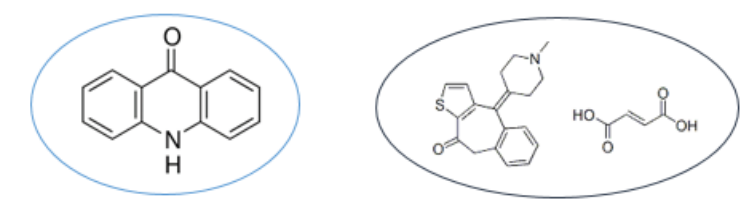

Original molecules or fragmentes of original molecules

Scheme 1. Proposed mechanism for quenching of ACD via the use of KTF as an injected sample.

Materials and Methods:

Apparatus and Reagents

A homemade ISNAG fluorimeter was used with 4-channels peristaltic pump (Ismatec, Switzerland) and Six-port medium pressure injection valve (I D E X corporation, USA) with sample loop (1 mm i.d. Teflon, variable length). Potentiometric recorder was used to estimate the output signals (Siemens, Germany (1- 5 V)). Spectrophotometer (UV-1800, shimadzu, Japan) was also used for classical spectrofluorometric methods.

All chemicals were used of analyticalreagent and distilled water was used to prepare all the solutions. A standard solution of $1 \mathrm{mmol} / \mathrm{L}$ and $50 \mathrm{mmol} / \mathrm{L}$ of $\mathrm{ACD}$ and $\mathrm{KTF}$, molecular weight 195.221 and $425.497 \mathrm{~g} / \mathrm{mole}$ respectively, were prepared by dissolving $0.0976 \mathrm{~g}$ of ACD in $500 \mathrm{~mL}$ of DMSO and $2.1275 \mathrm{~g}$ of KTF in $100 \mathrm{~mL}$ of distilled water. A pH range of 2.2-8.0 buffers were prepared according to Mcllvaine citric acidphosphate buffer systems (19). A series of sodium hydroxide solutions were prepared from the dilution of standardized stock solution $(0.1 \mathrm{~mol} / \mathrm{L})$ with distilled water.

\section{Sample Preparation}

Twenty tablets of two different pharmaceuticals drugs (Asmafort; Julphar and Gloditen; Globalpharma) containing $1 \mathrm{mg}$ of ketotifen fumarate were weighed, crushed, and grinded. A solution of $1 \mathrm{mmol} / \mathrm{L}$ was prepared by weighing 2.4474 and $3.8084 \mathrm{~g}$ (equivalent to 0.0213 $\mathrm{g}$ of active ingredient) from Asmafort, Julphar and Gloditen, Globalpharma respectively. Each one from the two kinds of sample was dissolved in distilled water. The solution was filtered to get rid of undissolved materials, the residue was washed with distilled water and completed the volume to 50 $\mathrm{ml}$ with the same solvent (distilled water).

\section{Methodology}

The manifold system composed of one line (Fig. 2) used for the flow injection system of ACD was used to determine the KTF using ISNAG fluorimeter with an experimental parameters of flow rate $2.75 \mathrm{~mL} / \mathrm{min}$ for the ACD and $150 \mu \mathrm{L}$ of 10 $\mathrm{mmol} / \mathrm{L} \mathrm{KTF}$ as an injected sample segment. These parameters were investigated to enhance the quenching of fluorescence of ACD; effect of ACD concentration using different concentration of ( 0.01 $0.05 \mathrm{mmol} / \mathrm{L}$ ) as a carrier stream, the effect of the flow rate of ACD as a carrier stream by changing their flow rate from 0.575 to $4.3 \mathrm{~mL} / \mathrm{min}$, variation of sample loop (50-250 $\mu \mathrm{L})$ were investigated, and the purged time were studied at $(2-25 \mathrm{sec})$.

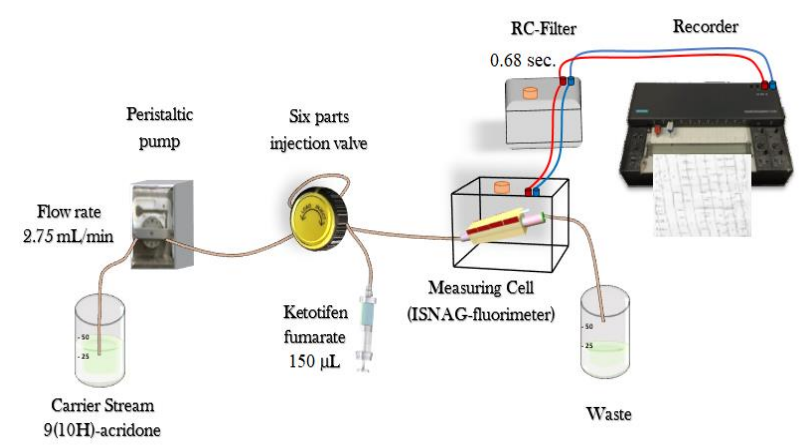

Figure 2. Single line manifold design of quenching system ACD-KTF.

\section{Results and Discussion:}

Study of the Optimum Parameters

Effect of Variable Concentration of 9(10H)acridone

A series of ACD (0.01-0.05 mmol/L) which is used as a continuous fluorescent molecule for the quenching system ACD-KTF at a flow rate of 2.75 
$\mathrm{mL} / \mathrm{min}, 150 \mu \mathrm{L}$ sample volume of $10 \mathrm{mmol} / \mathrm{L} \mathrm{KTF}$ were injected. Increasing ACD concentration up to $0.04 \mathrm{mmol} / \mathrm{L}$ gives a better quenching response (Fig. 3A) $0.04 \mathrm{mmol} / \mathrm{L}$ has been chosen as the best concentration due to its better quenching by KTF and its less effect by blank (D.W) as shown in Fig. 3B. These quenching of ACD fluorescence by KTF

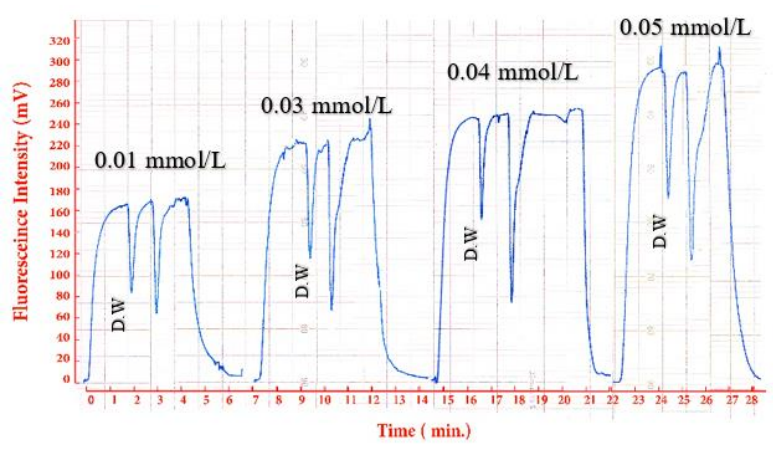

A might be due to several possibility non-radiative processes that lead to routes back to the ground electronic state. One process is the energy transfer between molecules through molecular collisions (i.e: external conversion, internal conversion and vibrational relaxation).

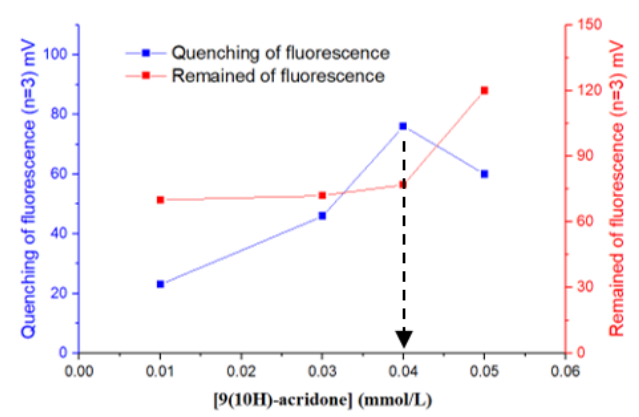

B

Figure 3. Variation of ACD concentration effect on A: Response profile-time, B: Quenching of fluorescence by KTF and remained of fluorescence.

\section{Physical Parameters Optimization Effect of Flow Rate}

Using $150 \mu \mathrm{L}$ of $\mathrm{KTF}(10 \mathrm{mmol} / \mathrm{L})$ as an injected sample segment in an open valve mode and $0.04 \mathrm{mmol} / \mathrm{L}$ of $\mathrm{ACD}$ as a carrier stream with flow rate range $(0.575-4.3 \mathrm{~mL} / \mathrm{min})$. It was noticed that there was a decreased in response height as well as in peak base width $\left(\Delta_{\mathrm{tb}}\right)$ with increasing the flow rate. A regular and sharp responses with narrow $\left(\Delta_{\mathrm{tb}}\right)$ were obtained at higher flow rate i.e. $>1.7$ $\mathrm{mL} / \mathrm{min}$ (Fig. 4). So, $2.2 \mathrm{~mL} / \mathrm{min}$ was chosen as the optimum flow rate to decrease the effect of dilution and dispersion which due to diffusion and convection. All the results tabulated in Table 1.

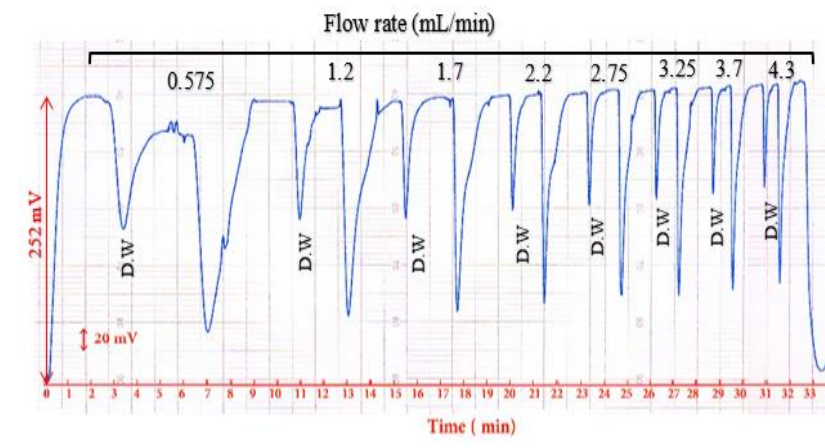

Figure 4. Variation of flow rate on response profile-time.

Table 1. Effect of variable flow rate of ACD-KTF quenched fluorescence system using $150 \mu \mathrm{L} \mathrm{of} 10 \mathrm{mmol} / \mathrm{L} \mathrm{of}$ KTF as an injected sample.

\begin{tabular}{|c|c|c|c|c|c|c|c|c|c|c|}
\hline \multirow{2}{*}{ 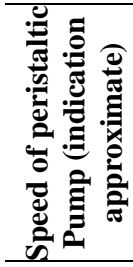 } & \multirow[t]{2}{*}{ 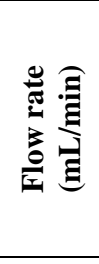 } & \multirow{2}{*}{\multicolumn{2}{|c|}{$\begin{array}{cc}\text { Total } & \text { Quenching of } \\
\text { quenching of } & \text { ACD } \\
\text { ACD } & \text { fluorescence } \\
\text { fluorescence } & \overline{\mathbf{y}}_{\mathrm{iQAF}}(\mathrm{mV}) \\
\overline{\mathbf{y}}_{\text {iTOAF }}(\mathbf{m V}) & \\
\text { Expressed as an average } \\
\text { peak heights }(\mathbf{n}=\mathbf{3}) \\
\end{array}$}} & \multirow[t]{2}{*}{$\stackrel{\stackrel{0}{\circ}}{\stackrel{2}{\approx}}$} & \multirow{2}{*}{$\begin{array}{c}\text { Confidence } \\
\text { interval of the } \\
\text { average } \\
\text { response (at } \\
95 \% \text { confidence } \\
\text { level) } \\
\overline{\mathbf{y}}_{\mathrm{i} 0} \pm \mathrm{t}_{0.05 / 2, \mathrm{n}-1} \sigma_{\mathrm{n}-1} / \sqrt{n}\end{array}$} & \multirow{2}{*}{ 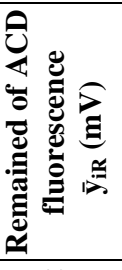 } & \multirow[t]{2}{*}{$\begin{array}{c}\Delta t_{b} \\
\text { Peak } \\
\text { base } \\
\text { width } \\
\text { (min) }\end{array}$} & \multirow[t]{2}{*}{$\begin{array}{l}\mathbf{V}_{\text {final }} \\
(\mathbf{m L})\end{array}$} & \multirow[t]{2}{*}{ v } & \multirow[t]{2}{*}{$\begin{array}{l}\text { Df } \\
=\frac{C_{0}}{C_{\text {final }}}\end{array}$} \\
\hline & & & & & & & & & & \\
\hline 5 & 0.575 & 204 & 86 & 0.97 & $86 \pm 2.062$ & 48 & 2.4 & 1.530 & 0.9804 & 10.1999 \\
\hline 10 & 1.200 & 188 & 84 & 0.67 & $84 \pm 1.3912$ & 64 & 1.5 & 1.950 & 0.7692 & 13.0005 \\
\hline 15 & 1.700 & 186 & 82 & 0.82 & $82 \pm 1.6645$ & 66 & 1.1 & 2.020 & 0.7426 & 13.4662 \\
\hline 20 & 2.200 & 185 & 83 & 1.12 & $83 \pm 2.3104$ & 67 & 0.9 & 2.130 & 0.7042 & 14.2005 \\
\hline 25 & 2.750 & 180 & 76 & 0.78 & $76 \pm 1.4658$ & 72 & 0.7 & 2.075 & 0.7229 & 13.8332 \\
\hline 30 & 3.250 & 182 & 76 & 0.91 & $76 \pm 1.7142$ & 70 & 0.7 & 2.425 & 0.6186 & 16.1655 \\
\hline 35 & 3.700 & 174 & 75 & 1.28 & $75 \pm 2.3850$ & 78 & 0.6 & 2.370 & 0.6329 & 15.8003 \\
\hline 40 & 4.300 & 170 & 78 & 0.83 & $78 \pm 1.6148$ & 82 & 0.5 & 2.300 & 0.6522 & 15.3327 \\
\hline
\end{tabular}

Response of continuous fluorescence: $252 \mathrm{mV} . \Delta_{\mathrm{tb}}(\mathrm{min})$ : Time lapse for the quenching of $9(10 \mathrm{H})$-acridone fluorescence by ketotifen fumarate within the measuring cell. Quenching of $9(10 \mathrm{H})$-acridone fluorescence by ketotifen fumarate $\bar{y}_{\text {iQAF }}(\mathrm{mV})=$ Total quenching of $9(10 \mathrm{H})$-acridone fluorescence by ketotifen fumarate $\bar{y}_{\mathrm{iTQAF}}(\mathrm{mV})$ - Quenching of $9(10 \mathrm{H})$-acridone fluorescence by D.W $\bar{y}_{\mathrm{iQ}}$ D.W. $(\mathrm{mV})$. 


\section{Effect of Sample Volume}

Flow rate $2.2 \mathrm{~mL} / \mathrm{min}$ for $0.04 \mathrm{mmol} / \mathrm{L}$ of ACD was used as a carrier stream with continuous fluorescence intensity of $252 \mathrm{mV}$, the injected volumes varied from $50-250 \mu \mathrm{L}$ in an open valve mode to study the effect of sample segment. It was noticed that an increase in the sample volume leads to an increase in the height of responses with a minor decrease or being approximately constant base peak width. Also, it was observed that when dealing with larger sample segment i.e $>100 \mu \mathrm{L}$ (Fig. 5) leads to increasing a significant difference between quenching of continuous fluorescence of ACD by KTF compared with distilled water (blank). Therefore, $100 \mu \mathrm{L}$ was chosen as the optimum sample volume that gave the maximum quenching of ACD fluorescence by KTF with minimum effect of blank.

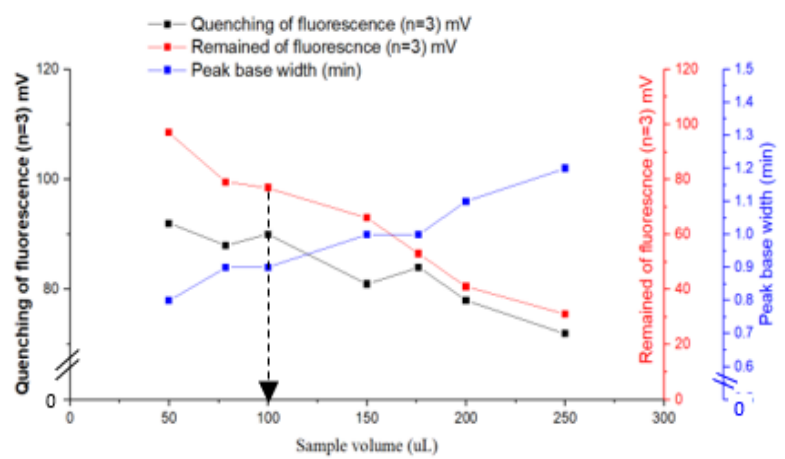

Figure 5. Effect of quenching of ACD fluorescence, remained of ACD fluorescence and peak base width.

\section{Purge Time Effect}

Using the optimum parameters achieved in previous study, different purge time $(2-20 \mathrm{sec})$ an addition to open valve mode $(25 \mathrm{sec})$ were studied. It is noticed that there is an increase in the response with increasing the allowed permissible time for the sample injection as shown in Fig. 6. Therefore, open valve mode was chosen as the best with maximum quenching of ACD fluorescence by KTF and minimum RSD\% (0.71\%).

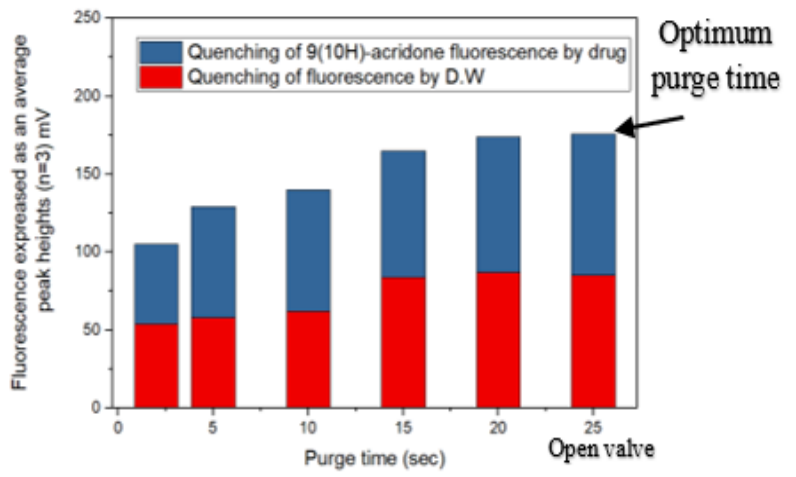

Figure 6. Quenching of ACD continuous fluorescence by KTF and quenching of ACD continuous fluorescence by blank vs. purge time.

\section{Calibration Graph for the Variation of KTF Concentration Versus Quenching of Fluorescence of ACD}

A series of KTF ranging from 1-50 mmol/L were prepared and injected on $0.04 \mathrm{mmol} / \mathrm{L}$ of ACD as a carrier stream using all achieved parameters in previous sections. A responses profile of total quenching of ACD fluorescence, quenching of ACD fluorescence by KTF and remained of ACD fluorescence (all in $\mathrm{mV}$ ) and the calibration graph obtained were plotted against the concentration of KTF. It was noticed from the linear calibration graph for the variation of KTF concentration gave a correlation coefficient $\mathrm{r}$ : $0.9762, \mathrm{r}^{2}: 0.9529, \mathrm{R}^{2} \%$ : $95.29 \%$ and the calculated $t$-value at $95 \%$ confidence level of 14.229 (Table 2). With range from $1-45 \mathrm{mmol} / \mathrm{L}$, above $45 \mathrm{mmol} / \mathrm{L}$ leading to deviation of correlation coefficient and deviate from linearity most probably due to the high intensity of the fluorescent molecule in front of detector which in turn to excessive collision of excited molecule causing as non-radiative emission process and quenching of fluorescence such as vibrational relaxation and internal conversion.

The method achieved in this work was compared with classical method (Spectrophotometric methods) via the measurement of absorbance spectrum at $\lambda_{\max }=302 \mathrm{~nm}$ (Fig. 7), calibration graph was obtained for classical spectrophotometric method and table 2 sum up all the results obtained using linear regression analysis for both methods. The limit of detection was calculated for the developed method and the reality and repeatability was studied for eight repeated injections for $(10$ and $30 \mathrm{mmol} / \mathrm{L})$ of Ketotifen fumarate (Fig. 8). 
Table 2. Summary of calibration graph results for quenching of ACD fluorescence by KTF at $95 \%$ confidence level.

\begin{tabular}{|c|c|c|c|c|c|c|}
\hline $\begin{array}{l}\text { Type of } \\
\text { method }\end{array}$ & $\begin{array}{l}\text { Measured } \\
\text { conc. } \\
\text { (mmol/L) }\end{array}$ & $\begin{array}{l}\text { Range of } \\
\text { calibration } \\
\text { graph } \\
(\mathrm{mmol} / \mathrm{L})\end{array}$ & $\begin{array}{c}\text { Equation of calibration graph } \\
\widehat{y}_{i}=a \pm S_{a} t+b \pm S_{b} t \\
{[\text { Ketotifen fumarate }] \text { mmol/L }} \\
\text { at confidence level } 95 \%, \mathrm{n}-2\end{array}$ & $\begin{array}{c}\mathbf{r} \\
\mathbf{r}^{2} \\
\mathbf{R}^{2} \%\end{array}$ & $\begin{array}{l}\mathrm{t}_{\mathrm{tab}}= \\
\mathrm{t}_{0.025} \\
\mathrm{n}-2\end{array}$ & $\begin{array}{c}\mathrm{t}_{\mathrm{cal}} \\
= \\
\frac{|r| \sqrt{n-2}}{\sqrt{1-r^{2}}}\end{array}$ \\
\hline \multirow{3}{*}{$\begin{array}{c}\text { Total } \\
\text { quenching of } \\
\text { fluorescence }\end{array}$} & \multirow[t]{3}{*}{$1-50$} & \multirow{3}{*}{$\begin{array}{c}1-45 \\
(n=12)\end{array}$} & \multirow{3}{*}{$\begin{array}{c}\hat{y}_{i}(\mathrm{mV})=134.98 \pm 11.34+2.96 \pm 0.47 \\
{[\text { Ketotifen fumarate }] \mathrm{mmol} / \mathrm{L}}\end{array}$} & 0.9762 & \multirow{3}{*}{\multicolumn{2}{|c|}{$2.228<<14.229$}} \\
\hline & & & & 0.9529 & & \\
\hline & & & & 95.29 & & \\
\hline \multirow{3}{*}{$\begin{array}{l}\text { Quenching of } \\
\text { fluorescence }\end{array}$} & & & \multirow{3}{*}{$\begin{array}{c}\hat{y}_{i}(\mathrm{mV})=50.98 \pm 11.34+2.96 \pm 0.47 \\
{[\text { Ketotifen fumarate }] \mathrm{mmol} / \mathrm{L}}\end{array}$} & 0.9762 & \multirow{3}{*}{\multicolumn{2}{|c|}{$2.228<<14.229$}} \\
\hline & & & & 0.9529 & & \\
\hline & & & & 95.29 & & \\
\hline \multirow{3}{*}{$\begin{array}{l}\text { Remained of } \\
\text { fluorescence }\end{array}$} & & & \multirow{3}{*}{$\begin{array}{c}\hat{y}_{i}(\mathrm{mV})=123.02 \pm 11.34-2.96 \pm 0.47 \\
{[\text { Ketotifen fumarate }] \mathrm{mmol} / \mathrm{L}}\end{array}$} & 0.9762 & \multirow{3}{*}{\multicolumn{2}{|c|}{$2.228<<14.229$}} \\
\hline & & & & 0.9529 & & \\
\hline & & & & 95.29 & & \\
\hline \multirow{3}{*}{$\lambda_{\max }=302 \mathrm{~nm}$} & 0.001-0.04 & $0.001-0.03$ & $\hat{y}_{i}=-0.01 \pm 0.02+59.63 \pm 1.28$ & 0.9997 & \multirow{3}{*}{\multicolumn{2}{|c|}{$2.365<<109.825$}} \\
\hline & & $(n=9)$ & [Ketotifen fumarate] $\mathrm{mmol} / \mathrm{L}$ & 0.9994 & & \\
\hline & & & & 99.94 & & \\
\hline
\end{tabular}

Limit of detection (Sample volume $=100 \mu \mathrm{L}$ )

Practical based on the gradual dilution for the minimum concentration $(0.7 \mathrm{mmol} / \mathrm{L})$

$0.298 \mathrm{~g} / \mathrm{L}$

$29.785 \mu \mathrm{g} / \mathrm{sample}$
Theoretical based on the value of slope $\mathrm{X}=3 \mathrm{~S}_{\mathrm{B}} /$ slope

$0.259 \mathrm{~g} / \mathrm{L}$

Repeatability

Theoretical (linear equation) based on the value of $\widehat{Y}=Y_{b}+3 S_{b}$ $4.520 \mathrm{~g} / \mathrm{L}$ $451.950 \mu \mathrm{g} / \mathrm{sample}$

[Ketotifen fumarate] $\mathrm{mmol} / \mathrm{L}$

$$
30
$$

Quenching of 9(10H)-acridone fluorescence by ketotifen fumarate expressed as an average peak heights $(\mathbf{n}=8) \overline{\mathbf{y}} \mathbf{i}(\mathbf{m V})$ 89.7
RSD\%

1.37
Confidence interval of the average response (at $95 \%$ confidence level) $\overline{\mathbf{y}}_{\mathrm{i}} \pm \mathrm{t}_{\mathbf{0 . 0 5} / 2, \mathrm{n}-\mathbf{1}} \sigma_{\mathrm{n}-1} / \sqrt{\boldsymbol{n}}$

$89.7 \pm 1.0285$

$147.4 \pm 1.0870$

$\mathrm{n}$ : No. of measurements in calibration graph, $\hat{y}_{i}$ : Estimated value in $\mathrm{mV}$ for developed method and absorbance for UVspectrophotometric method, $r$ : correlation coefficient, $r^{2}$ : coefficient of determination, $\mathrm{R}^{2} \%$ (Percentage capital $\mathrm{R}$-squared): explained variation as a percentage total variation. $X$ : value of L.O.D based on slope, $S_{B}$ : Standard deviation of blank repeated for 13 times, $Y_{b}$ : average response for blank $=$ intercept, $S_{\mathrm{b}}$ : standard deviation equal to $\mathrm{S}_{\mathrm{y} / \mathrm{x}}($ residual $), \mathrm{t}_{0.025,10}=2.228, \mathrm{t}_{0.025,7}=2.365$.

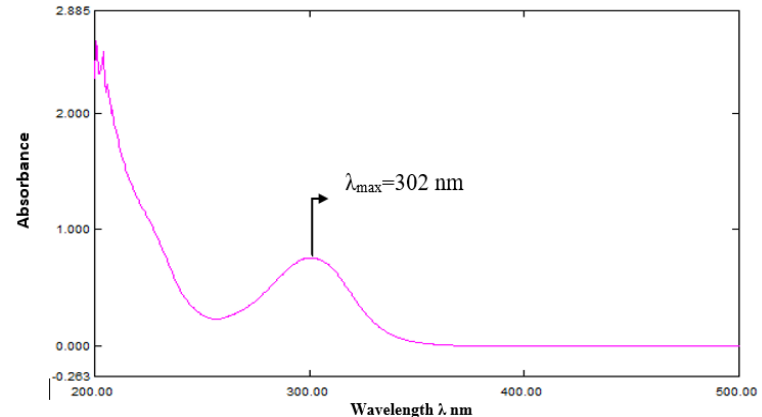

Figure 7. Absorbance spectrum of $0.01 \mathrm{mmol} / \mathrm{L}$ KTF with maximum wavelength of $302 \mathrm{~nm}$.

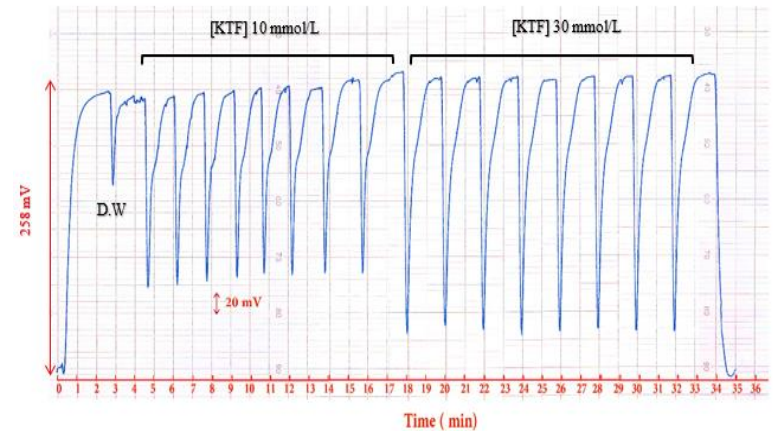

Figure 8. Repeatability response profile for quenching of ACD fluorescence by KTF.

\section{Assessment of the Use of ACD-KTF System Using ISNAG-fluorimeter \\ Two methods were used for the} determination of KTF in two different pharmaceutical drugs. The first method was the new developed methodology using ISNAG-fluorimeter and the second was the classical spectrophotometric method using maximum wavelength absorbance at $302 \mathrm{~nm}$ (1). A series of solutions were prepared of each pharmaceutical drug $\left(\begin{array}{lll}1 & \mathrm{mmol} / \mathrm{L})\end{array}\right)$ transferring $5 \mathrm{~mL}$ to each five volumetric flasks (10 $\mathrm{ml}$ ), followed by the addition of gradual volumes of standard KTF (20 mmol/L) for developed method, while for classical method solutions of $(0.01$ $\mathrm{mmol} / \mathrm{L}$ ) were prepared from the previous samples and $5 \mathrm{~mL}$ were transferred to each five volumetric flasks $(10 \mathrm{ml})$, followed by the addition of $(0.04$ $\mathrm{mmol} / \mathrm{L})$ standard ketotifen fumarate. Figure9 shows the calibration plot of these methods and the results were mathematically treated $(20,21)$ and tabulated in Table 3 at confidence level of $95 \%$. 


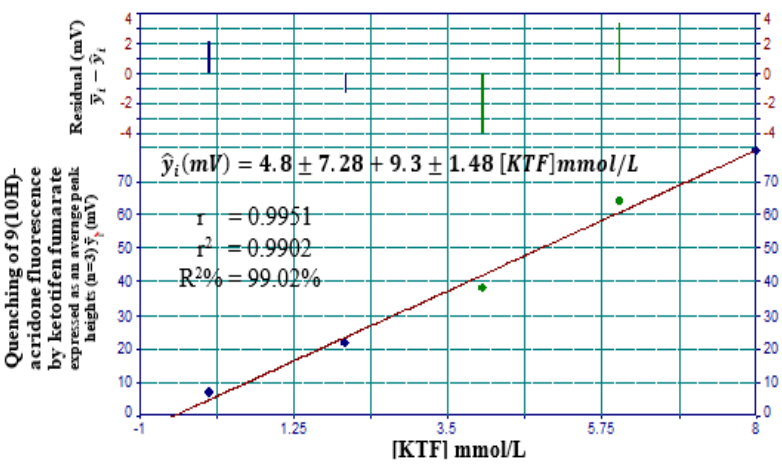

A

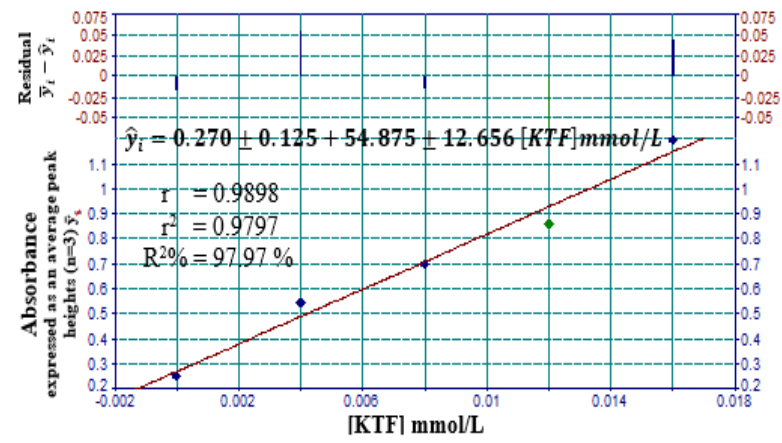

C

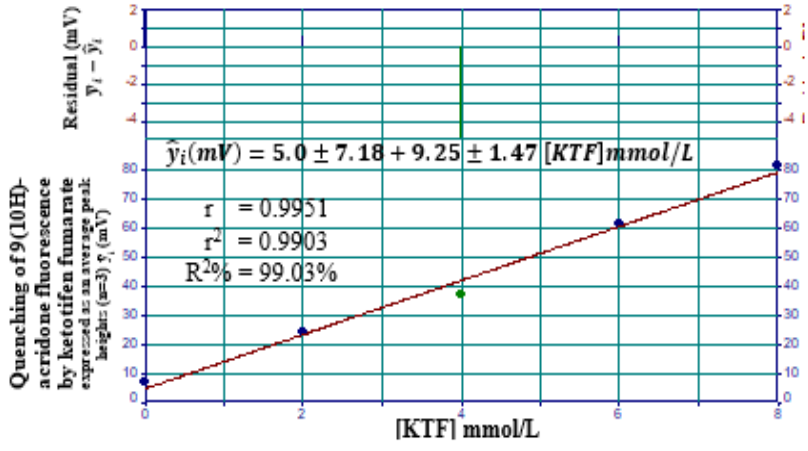

B

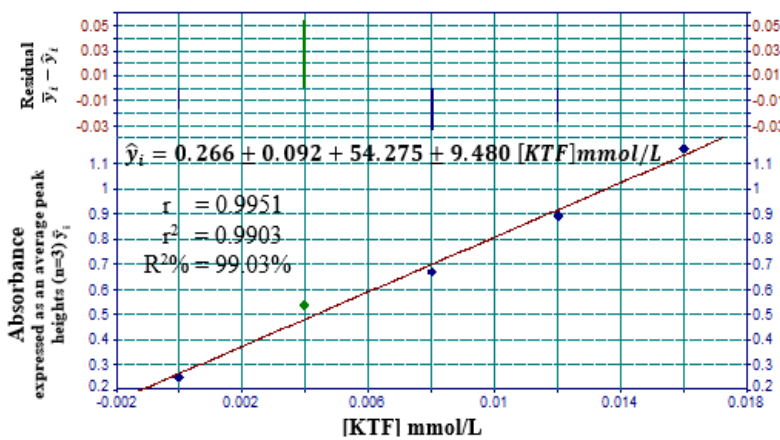

D

Figure 9: Standard addition graph for A- Developed method for Asmafort, B- Developed method for Gloditen, C-Classical method for Asmafort, D- Classical method for Gloditen. Residual $=\bar{y}_{i}($ practical value $)-\hat{y}_{i}($ estimated value $)$.

Table 3: Standard addition results for the determination of KTF in two different pharmaceuticals drugs using two methods.

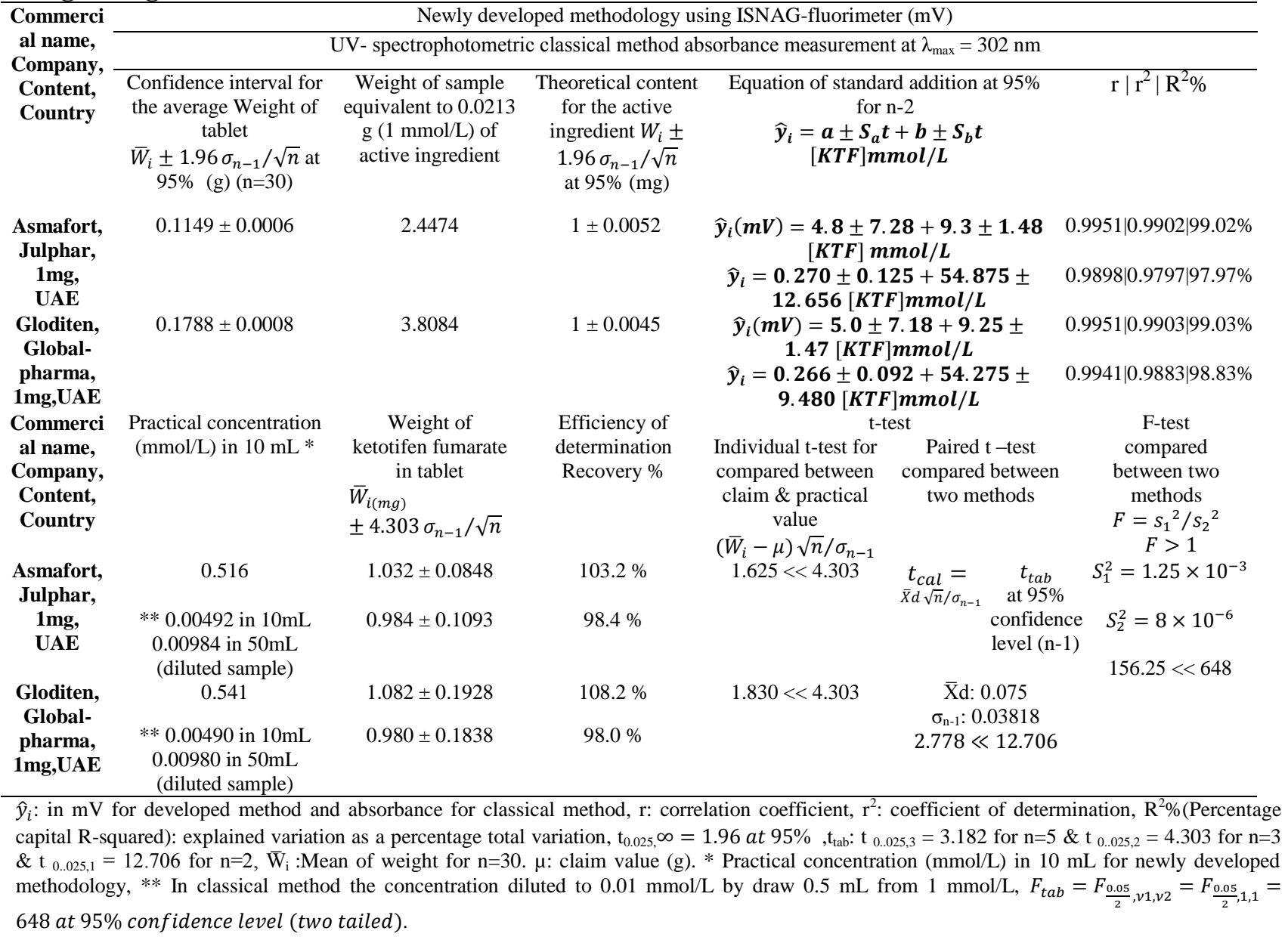




\section{Conclusion:}

The newly developed method was simple, sensitivities and rapid. The comparison between this work with classical spectrophotometric method via the t-test and F-test (the comparison tools) was shown that with no doubt that newly developed method (ISNAG procedure) is as good as the classical method. An alternative analytical method is found through this research work which is based on simple parameter conditions.

\section{Conflicts of Interest: None.}

\section{References}

1. Cartwright AC. The British pharmacopoeia, 1864 to 2014: medicines, international standards and the state: Routledge; 2016.

2. Sastry CS, Naidu PY. Spectrophotometric estimation of ketotifen fumarate in pharmaceutical formulations. Microchim Acta. 1997;127(3-4):219-23.

3. Al-Khazrajy O. Spectrophotometric Determination of Ketotifen Fumarate in Pure and Pharmaceutical Preperations by Bromophenol Blue Reagent. Ibn ALHaitham J Pure Appl Sci. 2016;24(3).

4. Singhvi I, Sachdeva D. Spectrophotometric estimation of ketotifen fumarate from tablet formulations. Indian J Pharm Sci. 2009;71(1):66.

5. Zagorodniy S, Monaykina Y, Vasyuk S. Quantitative Determination of Ketotifen in Drug dosage forms by Spectrophotometric method. IJAPBC; 2015.

6. Mokhtari A, Ghazaeian M, Maghsoudi M, Keyvanfard M, Emami I. Simple chemiluminescence determination of ketotifen using tris $(1,10$ phenanthroline) ruthenium (II) - Ce (IV) system. Luminescence. 2015;30(7):1094-100.

7. ZHANG X-1, MA H-y, WANG Y-n, WANG G, GAO C-y. Determination of Ketotifen Fumarate Based on the Chemiluminescence Reaction of Luminol with Potassium Permanganate. Phys Test Chem Anal (Part B: Chem Anal). 2015;7:029.

8. Frag EY, Mohamed GG, Khalil MM, Hwehy M. Potentiometric determination of ketotifen fumarate in pharmaceutical preparations and urine using carbon paste and PVC membrane selective electrodes. Int J Anal Chem. 2011;2011.

9. Mashhadizadeh MH, Jeilanpour H. Voltammetric Investigation of Ketotifen Using Carbon Paste Electrode Modified by Magnetic Core-Shell Fe3O4@, TMSPT Nanoparticles. Anal Bioanal Electrochem. 2014;6:308-20.

10. Karim-Nezhad G, Aliakbarloo F, Khorablou Z,
Dorraji PS. Enhancing the Sensitivity of Ketotifen Electrochemical Sensor Based on Electropolymerization of p-Aminobenzenesulfonic Acid on Glassy Carbon Electrode. Sens Lett. 2017;15(4):308-14.

11. Li L-j, Gao W-Y, Hu D-C, Cai Z, Li Y-Q. Electrochemiluminescence Method for Determination of Ketotifen Fumarate on Glassy Carbon Electrode Modified with Platinum-Multi-walled Carbon Nanotube Modified Electrode [J]. J Instrum Anal. 2010;11:003.

12. Zhou M, Li YJ, Ma YJ, Wang WF, Mi J, Chen H. Determination of ketotifen fumarate by capillary electrophoresis with tris $\left(2,2^{\prime}\right.$ - bipyridyl) ruthenium (II) electrochemiluminescence detection. Luminescence. 2011;26(5):319-23.

13. Wyszomirska E, Czerwińska K, Kublin E, Mazurek AP. Identification and determination of Ketotifen hydrogen fumarate, Azelastine hydrochloride, Dimetindene maleate and Promethazine hydrochloride by densitometric method. Acta Pol Pharm. 2013;70(6):951-9.

14. Kabra P, Nargund L, Murthy M. Development and Validation of a Stability-Indicating LC-UV Method for Simultaneous Determination of Ketotifen and Cetirizine in Pharmaceutical Dosage Forms. Trop J Pharm Res. 2014;13(7):1141-7.

15. Khater M, Issa Y, Mohammed SH. Flow injection determination of ketotifen fumarate using PVC membrane selective electrodes. Bioelectrochemistry. 2009;77(1):53-9.

16. Al-Awadie NST, Ibraheem MH. Quantitative determination of ketotifen fumarate in the pure form and tablets via the use of turbidity by reaction with cerium (iv) sulfate using ayah $6 \mathrm{~s} \times 1-\mathrm{t}-1 \mathrm{~d}$ cfi analyser. Int J Res Pharm Chem. 2016;6(3):411-31.

17. Al-Awadie NST, Ibraheem MH. Ketotifenfumarate determination via the new approach of turbidity formed by the reaction with phosphomolybdic acid using Ayah 6SX1-T-1D CFI Analyser. Int J Res Pharm Chem. 2016;6:230-48.

18. Sun C, Li X, Xu C, Zhang S, Chen K, Chen Q, et al. Determination of $9(10 \mathrm{H})$ - Acridone by HPLC with Fluorescence Detection. J Liq Chromatogr Relat Technol. 2007;30(2):245-54.

19. McIlvaine T. A buffer solution for colorimetric comparison. J Biol Chem. 1921;49:183-6.

20. Miller J, Miller JC. Statistics and chemometrics for analytical chemistry: Pearson Education; 2018.

21. Skoog DA, Holler FJ, Crouch SR. Principles of instrumental analysis: Cengage learning; 2017. 
طريقة فلورة جديدة لتقدير كيتوتيفين فيوماريت باستخدام تقنية الحقن الجرياني المستمر بوساطة مقياس

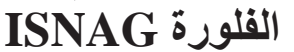

حيدر قيس منشد2
نغم شناكر تركي 1

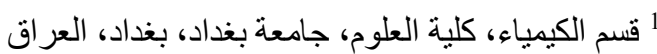

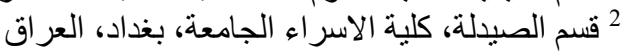

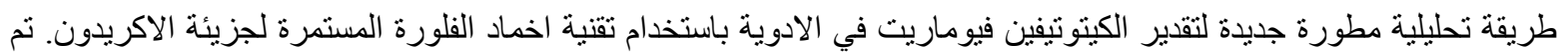

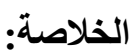

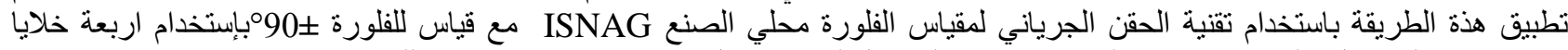

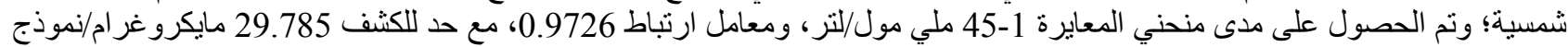

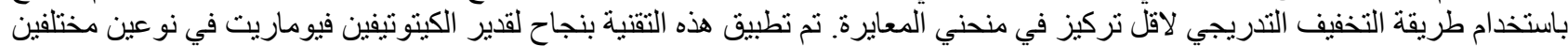

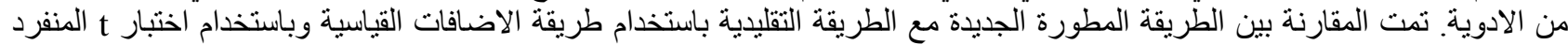
و المزدوج وكنلك اختبار F. تم ملاحظة عدم وجود اختلاف جو هري بين الطريقتين وبحدود ثقة 95\%ة.

الكلمات المفتاحية: أكريدون، تقنية الحقن الجرياني، فلورة، كيتوتنفين فيوماريت. 